\title{
Common marmosets Callithrix jacchus (Linnaeus, 1758) (Primates: Cebidae: Callitrichinae) in an urban mangrove: behavioral ecology and environmental influences \\ Saguis-de-tufos-brancos Callithrix jacchus (Linnaeus, 1758) (Primates: Cebidae: Callitrichinae) em um manguezal urbano: ecologia comportamental e influências do ambiente
}

\author{
Juliana Ribeiro de Albuquerquel (1) | Maria Adélia Borstelmann de Oliveiral (1) \\ Universidade Federal Rural de Pernambuco. Departamento de Morfologia e Fisiologia Animal. Recife, Pernambuco, Brasil
}

\begin{abstract}
The common marmoset (Callithrix jacchus) is a primate found in urban forests and in high density of human population sites, however there is insufficient informations about its behavior in mangroves. One group of marmosets was monitored in the Espaço Ciência museum, in the state of Pernambuco, Northeastern Brazil, located in a mangrove area that has been deforested for years, but has a few remaining fragments. We used scan sampling and all occurrences methods for behavioral data collection, between September 2012 and February 2013. Moving was the most frequent behavior, occupying $24.4 \%$ of the behavioral repertoire and human-provided food made up 52\% of their diet. The group of marmosets interacted with people, wild and domestic animals and objects introduced by humans, such as buckets and nets for collecting organic material belonging to other research projects. While the urban environment offered conditions for group establishment in the study area, the inclusion of human foods in the diet and the relation of the marmosets with various abiotic and biotic components of the landscape endanger the health and survival, and that of other animals and people involved in the interactions.
\end{abstract}

Keywords: Activity pattern. Callithrix. Diet. Urban space.

Resumo: O sagui-de-tufos-brancos (Callithrix jacchus) é um primata encontrado em florestas urbanas e em locais de alta densidade humana, mas não há informações suficientes sobre seu comportamento em áreas de manguezal. Um grupo de saguis foi monitorado no museu Espaço Ciência, no estado de Pernambuco, Nordeste do Brasil, construído em uma área de manguezais que sofreu devastações durante anos e mantém, dentro dos seus limites, um dos poucos fragmentos que restou. Para a coleta de dados comportamentais, foram utilizados os métodos varredura instantânea e todas as ocorrências, entre setembro de 2012 e fevereiro de 2013. Locomoção foi o comportamento mais frequente, ocupando $24,4 \%$ do repertório comportamental, e alimentos providos compuseram $52 \%$ da sua dieta. O grupo de saguis interagiu com pessoas, animais do manguezal, animais domésticos e com objetos inseridos por humanos, como baldes e redes para coleta de material orgânico pertencentes a outros projetos de pesquisa. Enquanto o ambiente urbano ofereceu condições para o estabelecimento do grupo na área de estudo, a inclusão de alimentos antropogênicos na dieta e a relação dos saguis com variados componentes abióticos e bióticos da paisagem colocaram em risco a saúde e a sobrevivência dos saguis, dos demais animais e das pessoas envolvidos nas interações.

Palavras-chave: Padrão de atividades. Callithrix. Dieta. Espaço urbano.

AlBuQueRQuE, J. R. \& M. A. B. OlIVEIRA, 2020. Common marmosets Callithrix jacchus (Linnaeus, 1758) (Primates: Cebidae: Callitrichinae) in an urban mangrove: behavioral ecology and environmental influences. Boletim do Museu Paraense Emílio Goeldi. Ciências Naturais 15(3): 617-632. DOI: http://doi.org/10.46357/bcnaturais.v15i3.219.

Autora para correspondência: Juliana Ribeiro de Albuquerque. Universidade Federal Rural de Pernambuco. Departamento de Morfologia e Fisiologia Animal. Rua Dom Manuel de Medeiros, s/n - Dois Irmãos. Recife, PE, Brasil. CEP 52171-900 (julidealbuquerque@gmail.com). Recebido em 01/12/2019

Aprovado em 10/11/2020

Responsabilidade editorial: Alexandra Maria Ramos Bezerra
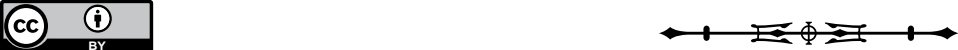


\section{INTRODUCTION}

The accelerated growth of urban landscapes and the ecological consequences of this growth are topics of interest and frequent research, regarding the various aspects related to environmental and human health (Bradley \& Altizer, 2007; Mucelin \& Bellini, 2008). Urbanization modifies the landscape, promotes physical and biological changes over time, compromises ecosystems, and causes environmental impacts such as, the reduction of natural vegetation and the home range of animals (Adams, 2005; McKinney, 2008). Humans see wild species as problems when these species occur near human activities. However, interactions with humans can affect the health of wild animals (Angelici, 2016). The presence of wild animals in urban environments is not uncommon and as such, it is likely that the increasing proximity of these animals to humans is expected. Soulsbury \& White (2015) explain that wild animals and humans in urban areas inevitably interact. Yet, the nature of these interactions can vary greatly from admiration, pleasure, fear and loathing (Soulsbury \& White, 2015).

Urban areas offer opportunities to study questions on anthropogenic influence on wild animals and natural processes (Parker \& Nilon, 2012). From the point of view of behavioral ecology and wildlife conservation, studies on wildlife living in urban environments are relevant and have been increasing over the last few decades (Marion, 1988; Hadidian, 1992; Hadidian \& Smith, 2001; Magle et al., 2012; Poessel et al., 2017). The process of wild animals adjusting to live in urban conditions is known as synurbization (Luniak, 2004; Adams, 2005). Humans living in high densities and the type of activities they perform play an important role in determining which species are able to adjust to urban ecosystems and how this adjustment affects their behavior (Soulsbury \& White, 2015). Animal behavioral responses to urbanization can be classified into three types (Goulart et al., 2010): (1) animals that avoid contact or fail to thrive in urban environments; (2) urban explorers: animals living in higher densities in urban environments compared to their natural environments, and (3) urban adapters: animals living in the same densities in both their urban and natural environments.

Several species can survive in environments that suffer from anthropic disturbance. Important adjustments for the successful establishment of these animals in urban environments include anthropogenic foods in their diet, animals may increase their circadian activity and/ or decrease the constancy of their migratory behavior (Lowry et al., 2013). These adjustments can result in behavioral changes, allowing for better interactions with the environment and among conspecifics (Jokimäki et al., 2011). This is the case of the common marmoset Callithrix jacchus (Linnaeus, 1758), a Neotropical primate commonly found in Brazilian urban areas within parks, gardens, yards, and villages (Rangel et al., 2011; Silva, G. et al., 2011; Albuquerque et al., 2012; Silva, J. et al., 2014).

Callithrix jacchus is native in Northeastern Brazil, occurring in the Caatinga, Atlantic Forest, Cerrado and associated habitats such as mangrove forests (Silva, G. \& Monteiro da Cruz, 1993; Paula et al., 2005; Rylands et al., 2009; Rylands \& Mittermeier, 2013). In Southeastern Brazil, the species was introduced as a result of animal trafficking (Ruiz-Miranda et al., 2000; Rangel et al. , 2011). All literature available on C. jacchus in urban areas, focuses on their occurrence in Atlantic Forest areas (Silva, G. \& Monteiro da Cruz, 1993; Mendes Pontes \& Soares, 2005; Cunha et al., 2006; Lyra-Neves et al., 2007; Silva, M. et al., 2018), as well as several studies focusing mainly on their behavioral ecology within urban parks or densely populated places by humans (Silva, G. et al., 2011; Traad et al., 2012; Silva, J. et al., 2014).

Little is known about the behavior of primates in urban mangroves due to the scarcity of research on this type of habitat (Cutrim, 2013). Mangrove ecosystems are heterogeneous habitats with an unusual variety of animals and plants adapted to the extreme environmental conditions of high salinity, frequent submersion and a 
soft-bottomed anaerobic mud (Khairnar et al., 2009). Depending on climate, land conditions, or human impact, species of mangrove vegetation and animal species may vary and this variation ranges from microfauna to large mammals, including resident and occasional populations and individuals, such as generalist carnivores and primates (Vannucci, 2001).

The aims of this study were: (1) to monitor and describe the behavioral and ecological repertoire of a group of common marmosets (C. jacchus) in an urban mangrove fragment; (2) investigate the influence of factors associated with urbanization, including the effect of human presence on the group's behavior; (3) evaluate how these influences develop; and (4) how these factors affect the welfare of marmosets.

\section{MATERIAL AND METHODS}

\section{STUDY AREA}

This study was carried out in the Espaço Ciência museum, located in Olinda, a city adjacent to Recife, the capital of Pernambuco state, Northeastern Brazil (Figure 1). The museum has a total area of 12 hectares (Figure 2). It is the largest open science museum in the country (SECTEC, 2016), with areas where visitors circulate and two hectares of an urban mangrove called

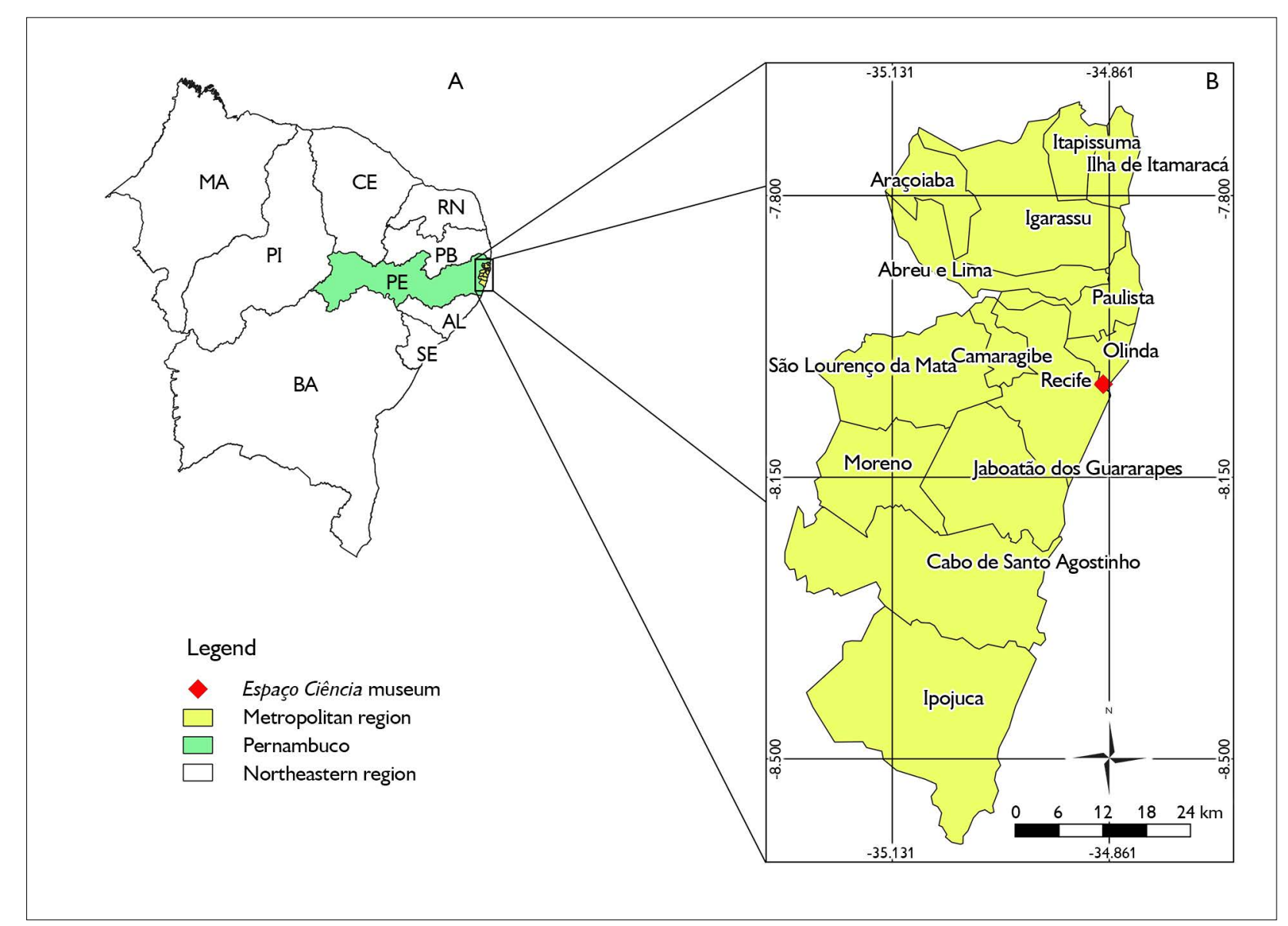

Figure 1. A) Map shown Pernambuco state highlighted (green) within the Northeastern region of Brazil; B) Recife and the Metropolitan Region cities (yellow), where the red dot indicates the location of the Espaço Ciência museum, at the city limits of Recife and Olinda municipalities. Sources: adapted from IBGE (2020) and PCR (2020). 


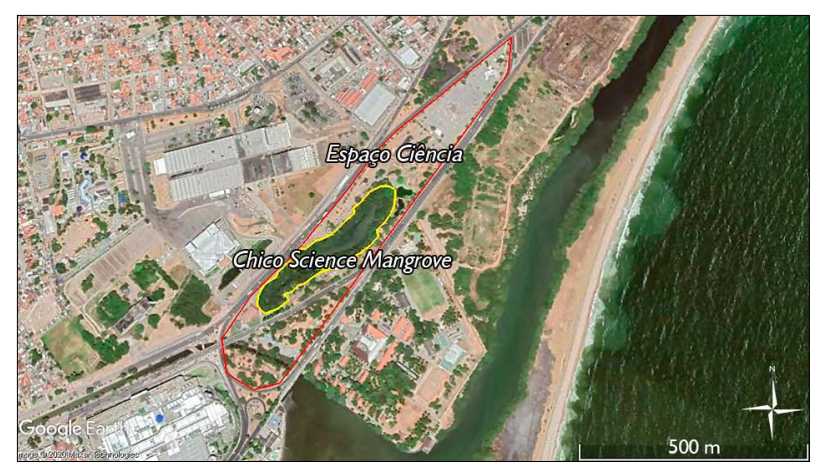

Figure 2. Satellite image of the study area, Espaço Ciência museum (red outline) and the Chico Science Mangrove (yellow outline). Source: Google Earth ${ }^{\circledR}$.

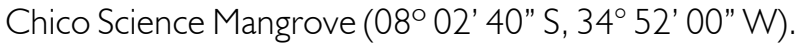
This mangrove fragment is located approximately $500 \mathrm{~m}$ from the Atlantic Ocean, at the mouth of two important rivers in the region, the Beberibe and Capibaribe. Its vegetation is in regeneration, with trees reaching approximately five meters, consisting mainly of red mangrove Rhizophora mangle (Linnaeus, 1753) (Rhizophoraceae), white mangrove Laguncularia racemose (Linnaeus, 1807) (Combretaceae) and black mangrove Avicennia schaueriana (Stapf \& Leechman, 1939) (Acanthaceae) species. Several species of resident and migratory birds feed and reproduce in this mangrove forest (Periquito et al., 2008).

The Espaço Ciência is surrounded by highways, named the Salgadinho Complex, located in the vicinity of the northern boundary of the fluvial-marine plain of Recife. The landscape of the study area has undergone profound transformations between the years 1970 and 2000, when the original mangrove area was, for years, cut down for the construction of the Salgadinho Complex and later chosen for the development of urban residences and commercial areas (Souza, 2006).

\section{SUBJECTS AND DATA COLLECT}

One group of common marmosets, C. jacchus, was monitored. The group was the only one found to inhabit the mangrove and adjacent areas of the museum (Figure 3).

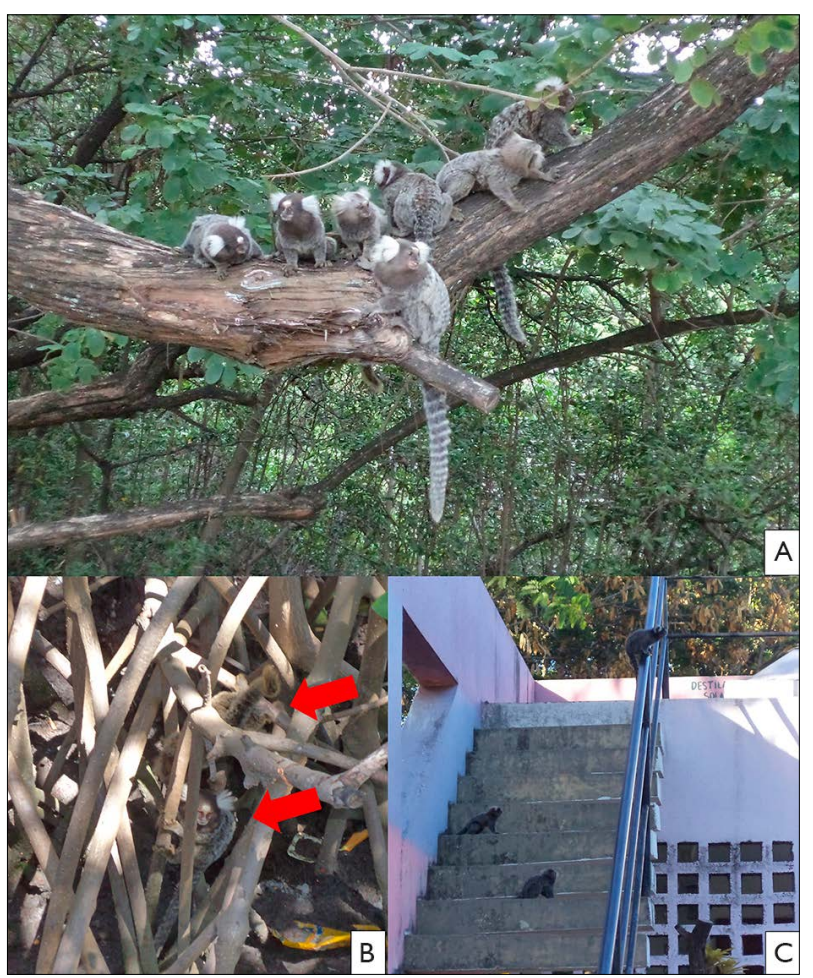

Figure 3. Group of the study marmosets, Callithrix jacchus (A), at the edge of the Chico Science Mangrove. (B) Two marmosets of the group (indicated by arrows) between the roots of the mangroves during foraging, and (C) three marmosets in a built-up area of the Espaço Ciência museum visitation area. Photos: Juliana Ribeiro de Albuquerque (2012).

During the observations, the animals were individually identified by age, estimated by morphological and behavioral characteristics (body size, length of periauricular tufts). Infants were identified through their being carried and fed by older animals: infant $\leq 5$ months, juvenile 6-10 months, subadult 11-15 months and adult $>15$ months (Yamamoto, 1993; Albuquerque et al., 2012), sex (male or female) and by marks such as scars or distinguishable physiognomy whenever possible. Group size varied between eight and ten animals due to births and dispersions. The composition of the group at the end of the study was eight animals: two adults (one male and one female), two subadults (one male and one female), two young (one male and one of unidentified sex), and two infants of unidentified sex.

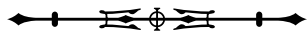


Data were collected from September 2012 to February 2013, throughout the dry season. Observations occurred every month, twice a week, with each period of observation lasting three hours, totaling 150 hours of sampling effort. We used the scan sampling and all occurrences methods (Altmann, 1974) for behavioral data collection. The first behavior displayed and the distances of each animal from the nearest neighbor were described during sessions of five minutes, alternated with five minutes of pause, totaling ten minutes for each scan.

The all occurrences method was applied throughout the observation period, including during the scan period, for the detailed recording of rare or uncommon behaviors and when these behaviors were associated with the presence of biotic or abiotic elements typical of an urban environment. All data were recorded on field recording sheets and, additionally, moments of foraging and feeding behavior were recorded with a digital camera (Sony ${ }^{\circledR}$, DSC-S 3000).

\section{STATISTICAL ANALYSES}

Descriptive statistical analyses and analyses of variance (ANOVA) complemented with the Tukey test were conducted. These tests made it possible to compare the difference between the most frequent behavioral activities and the occurrence of food seeking behaviors (foraging) and consumption (feeding), in the museum's visiting areas and in the mangrove. The Bioestat software version 5.3 was used to perform the descriptive and variance analyses, considering a significant result at $p<$ 0.05 and highly significant at $p<0.01$.

\section{RESULTS}

\section{ACTIVITIES PATTERN}

For 144 hours of the total 150 hours of sampling effort, 912 sessions of scan were performed and 2,936 behavior records of $C$. jacchus group were collected.
Thirty-three behaviors were exhibited by the group of marmosets (Table 1), with a variable pattern between individual and social activities, including both affiliative and agonistic behaviors. Some individual, affiliative and all low agonistic behaviors ( $n \leq 88)$ were grouped into a single behavioral category, in which case six categories were included: 1 - Social grooming; 2 - Parental care; 3 - Other individual behaviors; 4 Agonistic behaviors; 5 - Other affiliative behaviors; and 6 - Defecate or urinate.

Callithrix jacchus individuals spent a considerable percentage of time moving (24.4\%), followed by resting (15.5\%), stationary (13.7\%), foraging (12.4\%), playing (9.5\%), feeding (6\%) and social grooming (5.7\%) behaviors. The categories of agonistic behaviors (1\%), other affiliative behaviors $(0.4 \%)$, interact with people $(0.5 \%)$, defecate or urinate $(0.1 \%)$ and interact with animals $(0.03 \%)$ were expressed for less than $2 \%$ of their activity repertoire (Table 2 ).

The relationships between the monthly means of the highest percentage for each of the seven behavioral categories are shown in Table 3. Mean of moving (119.3 $\pm 30.1)$ was highly significant in relation to resting (76.2 $\pm 16.3)(p<0.01)$, stationary $(67.2 \pm 16.3)(p<0.01)$, foraging $(60.5 \pm 20.6)(p<0.01)$, feeding $(29.5 \pm$ 18.4) $(p<0.01)$, social grooming $(27.8 \pm 9.3)(p<$ $0.01)$ and playing $(46.7 \pm 15.2)(p<0.01)$ behaviors. Resting had a highly significant mean in relation to the other categories (feeding, social grooming and moving, $p<0.01$ in each behavior). Stationary behaviors presented a significantly different mean $(p<0.05)$ in relation to the means of feeding, social grooming and this category was even more significant $(p<0.01)$ when compared to moving. The difference between foraging and playing behaviors was only significant in relation to the moving category $(p<0.01)$. Feeding had a significantly different mean $(p<0.05)$ compared to the stationary behavior category and was significant $(p<0.01)$ compared to resting and moving behaviors. 
Table 1. Behavioral categories and their respective descriptions (adapted from Monteiro da Cruz, 1998), referring to the activities pattern of the group of C. jacchus observed between September 2012 and February 2013 in the Espaço Ciência museum, Olinda, Pernambuco state, Brazil.

\begin{tabular}{|c|c|}
\hline Behaviour & Description \\
\hline Moving & Move slowly or fast \\
\hline Jump & Movement without physical contact with any substrate by jumping \\
\hline Resting & Lie in relaxed posture, closing its eyes or not \\
\hline Stationary & Remain still, but attentive to the environment \\
\hline Foraging & Search for natural or processed foods \\
\hline Feeding & Chew, eat or carry food in the mouth \\
\hline Social grooming & $\begin{array}{l}\text { Included the behaviors involving cleaning the hair of another marmoset and being cleaned by another } \\
\text { marmoset, either involving two or more marmosets simultaneously }\end{array}$ \\
\hline Playing & Act of running or fighting, pursuing or grabbing another marmoset without apparent intentions \\
\hline Defecate or urinate & It included the excretion of faeces or urine \\
\hline Parental care & $\begin{array}{l}\text { Included behaviors: nurse or infant (carrying nursing behaviors feeding breast milk to the infant or } \\
\text { transporting infants on the back or under the breast) and: be breastfed or to be carried (act of an infant } \\
\text { feeding from breast milk or being transported on the back or under the breast of another marmoset) }\end{array}$ \\
\hline $\begin{array}{l}\text { Other individual } \\
\text { behaviors }\end{array}$ & $\begin{array}{l}\text { Individual behaviors (itching, autogrooming, marking, gnawing tree barks, vocalizing, hiding) emitted with } \\
\text { low frequency by marmosets }\end{array}$ \\
\hline Agonistic behaviors & $\begin{array}{l}\text { Included behaviors involving running away, running away from the observer, chasing, being chased, } \\
\text { bristling hair, stealing food, attempting to steal food and applying spankings }\end{array}$ \\
\hline Other affiliative behaviors & $\begin{array}{l}\text { Included affiliative behaviors such as contacting or approaching performed with low frequency by } \\
\text { marmosets }\end{array}$ \\
\hline Interaction with people & Interacting directly or indirectly with people \\
\hline Interaction with animals & Interacting directly or indirectly with animals (pets or not) \\
\hline
\end{tabular}

Table 2. Behavioral categories, total number of occurrences $(\mathrm{N})$ and equivalent percentage (\%) obtained for the Callithrix jacchus group observed in the Espaço Ciência museum, Olinda, Pernambuco state, Brazil.

\begin{tabular}{l|c|c}
\multicolumn{1}{c|}{ Categories } & $\mathrm{N}$ & (Continue) \\
\hline Moving & 716 & 24.4 \\
\hline Jump & 35 & 1.2 \\
\hline Resting & 457 & 15.5 \\
\hline Stationary & 403 & 13.7 \\
\hline Foraging & 363 & 12.4 \\
\hline Feeding & 177 & 6.0 \\
\hline Social grooming & 167 & 5.7 \\
\hline Playing & 280 & 9.5 \\
\hline Defecate or urinate & 3 & 0.1 \\
\hline Parental care & 161 & 5.5 \\
\hline Other individual behaviors & 119 & 4.1 \\
\hline
\end{tabular}


Table 2.

\begin{tabular}{l|c|c}
\multicolumn{1}{c|}{ Categories } & $\mathrm{N}$ & $\%$ \\
\hline Agonistic behaviors & 27 & 1.0 \\
\hline Other affiliative behaviors & 13 & 0.4 \\
\hline Interaction with people & 14 & 0.5 \\
\hline Interaction with animals & 1 & 0.03 \\
\hline Total & 2,936 & 100 \\
\hline
\end{tabular}

Table 3. Monthly mean values (Mean C1 and C2), difference between the means (Difference), studentized range distribution (Q) and $p$ of the means for the seven most frequent behavioral categories in the Callithrix jacchus group, observed in the Espaço Ciência museum, Olinda, Pernambuco state, Brazil. Legends: C1 = first category of the line; C2 = second category of the line; ns = not significant.

\begin{tabular}{|c|c|c|c|c|}
\hline Categories & Mean $\mathrm{C} 1$ and $\mathrm{C} 2$ & Difference & Q & $\mathrm{p}$ \\
\hline Moving (C1) and Resting (C2) & 119.3 and 76.2 & 43.1 & 5.6 & $<0.01$ \\
\hline Moving (C1) and Stationary (C2) & 119.3 and 67.2 & 52.1 & 6.8 & $<0.01$ \\
\hline Moving (C1) and Foraging (C2) & 119.3 and 60.5 & 58.8 & 7.6 & $<0.01$ \\
\hline Moving (C1) and Feeding (C2) & 119.3 and 29.5 & 89.8 & 11.7 & $<0.01$ \\
\hline Moving (C1) and Social grooming (C2) & 119.3 and 27.8 & 91.5 & 11.9 & $<0.01$ \\
\hline Moving (C1) and Playing (C2) & 119.3 and 46.7 & 72.6 & 9.4 & $<0.01$ \\
\hline Resting (C1) and Stationary (C2) & 76.2 and 67.2 & 9.0 & 1.1 & ns \\
\hline Resting (C1) and Foraging (C2) & 76.2 and 60.5 & 15.7 & 2.0 & ns \\
\hline Resting (C1) and Feeding (C2) & 76.2 and 29.5 & 46.7 & 6.09 & $<0.01$ \\
\hline Resting (C1) and Social grooming (C2) & 76.2 and 27.8 & 48.4 & 6.3 & $<0.01$ \\
\hline Resting (C1) and Playing (C2) & 76.2 and 46.7 & 29.5 & 3.8 & ns \\
\hline Stationary (C1) and Foraging (C2) & 67.2 and 60.5 & 6.7 & 0.8 & ns \\
\hline Stationary (C1) and Feeding (C2) & 67.2 and 29.5 & 37.7 & 4.9 & $<0.05$ \\
\hline Stationary (C1) and Social grooming (C2) & 67.2 and 27.8 & 39.4 & 5.1 & $<0.05$ \\
\hline Stationary (C1) and Playing (C2) & 67.2 and 46.7 & 20.5 & 2.6 & ns \\
\hline Foraging (C1) and Social grooming (C2) & 60.5 and 27.8 & 32.7 & 4.2 & ns \\
\hline Foraging (C1) and Playing (C2) & 60.5 and 46.7 & 13.8 & 1.8 & ns \\
\hline Foraging (C1) and Feeding (C2) & 60.5 and 29.5 & 31.0 & 4.0 & ns \\
\hline Feeding (C1) and Social grooming (C2) & 29.5 and 27.8 & 1.7 & 0.2 & ns \\
\hline Play (C1) and Feeding (C2) & 46.7 and 29.6 & 17.1 & 2.2 & ns \\
\hline Play (C1) and Social grooming (C2) & 46.7 and 27.8 & 18.9 & 2.4 & ns \\
\hline
\end{tabular}

\section{DIET}

Foraging areas used by the $C$. jacchus group included sites such as the Chico Science Mangrove, the medium and large trees of the surrounding area for visitors and the areas with buildings. The diet of the marmosets $(n=177)$ included natural foods such as gum (11\%), fruits (0.6\%), flowers $(0.6 \%)$, invertebrates $(1.1 \%)$, vertebrates $(2 \%)$ and human-provided food (52\%), as well as food that could not be classified (33\%) (Figure 4). Foods classified as human-provided were obtained under the following 


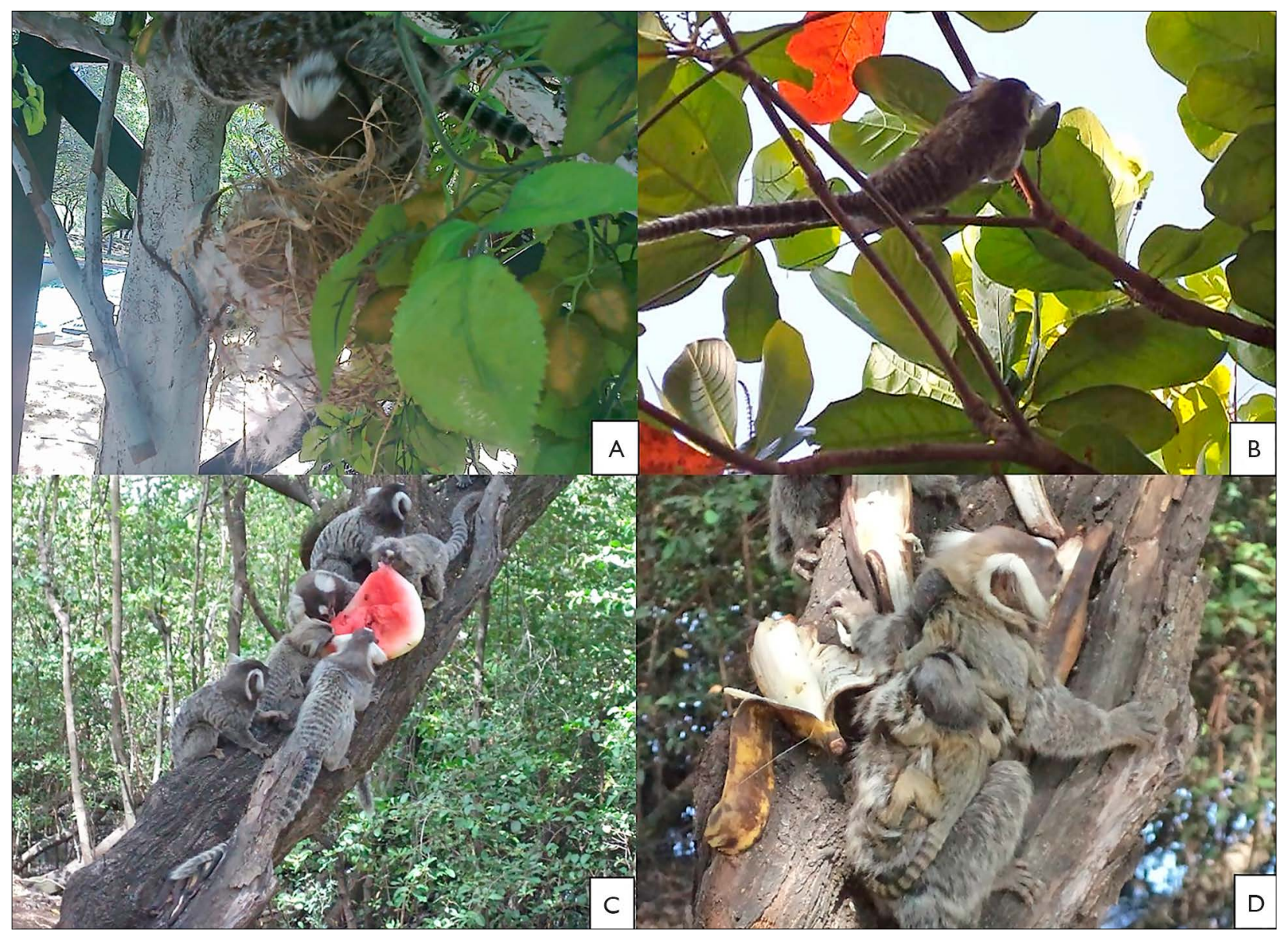

Figure 4. Marmosets during feeding. Eating bird eggs from a nest in an artificial tree (A), during the gomivory of tree of the species Terminalia catappa (B), eating watermelon (C), and marmoset with infants on their back, eating bananas (D). In these last two cases the food was provided by people. Photos: Juliana Ribeiro de Albuquerque (2012).

conditions: a) interaction with visitors and workers, b) removed from the garbage or on the soil, and c) food disposed by humans. In addition to the cited items, the marmosets were observed eating bird eggs, in a nest built on an artificial tree constructed by the museum.

Gum was obtained from trees of Terminalia catappa (Linnaeus, 1767) (Combretaceae) and unindentified Leguminosae species. The only fruits identified as food were figs (Ficus sp., Moraceae) and a flower from an unidentified plant was also recorded. Among humanprovided foods were various fruits (banana, papaya and watermelon), popcorn and cookies. Arthropods consumed were exclusively orthopterans and vertebrates consumed were lizards (Squamata). Gum, fruits, flowers and eggs were acquired in the museum's visiting area, and humanprovided food, insects and vertebrates were obtained both in the visitation area and in the mangrove.

ENVIRONMENTAL INTERFACE:

REFLECTIONS OF THE URBAN LANDSCAPE ON THE BEHAVIOR OF THE GROUP OF COMMON MARMOSETS

The Espaço Ciência museum occupies 12 hectares, with several outdoor areas for visitors to move around freely, administrative and experimental buildings and the Chico Science Mangrove with 2 hectares. The home range of

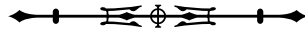


the marmosets group covered only the mangrove and the visitation area around it. Almost half of the activity occurred (49.3\%, $n=1,447)$ in the mangrove and $50.7 \%(n=$ 1,489 ) occurred in the museum visitation area. There was no significant difference in the use of space between the two sites (ANOVA, $F=0.0211, p=0.8821$ ).

The descriptive analysis of the seven most common behaviors (Table 4) shows that moving, resting, foraging and social grooming occurred most often in the mangrove and the stationary, playing and feeding activities occurred mainly in the visitation area of museum. The ANOVA test did not indicate significant differences between moving $(F=0.1657, p=0.6937)$, resting $(F=0.0483, p=$ 08245), stationary $(F=0.1763, p=0.6851)$ playing $(F=1.6905, p=0.2212)$, feeding $(F=1.3835$, $p=0.2662)$, and social grooming $(F=0.8029, p=$ $0.6052)$ in the mangrove or visitation area. Regarding the activities associated with diet, i.e., foraging and feeding, it was evident that foraging was, on average, more frequent than feeding, in the mangrove $(p<0.05)$ (Table 5).

Direct (for example, the person fed the marmoset directly, initiating physical contact) or indirect contact (the person placed the food in a certain place where it could be reached by a marmoset) between humans and marmosets ( $n=14,0.5 \%$ ) related to food provisioning was observed. The people involved in the interactions with marmosets were visitors, museum workers, groundskeepers and snack merchants who passed through the visitor areas and who provided food items to the marmosets in order to observe their behaviors more closely.

Table 4. Behavioral categories, total number of occurrences $(\mathrm{N})$, minimum and maximum values (Min-Max) of monthly occurrence recorded during the research, total amplitude $(\mathrm{Ta})$, monthly mean and standard deviation $(\mu \pm \mathrm{SD})$ obtained for the Callithrix jacchus group by area use, observed in the Espaço Ciência museum, Olinda, Pernambuco state, Brazil.

\begin{tabular}{l|c|c|c|c|c|c|c|c}
\hline \multirow{2}{*}{ Categories } & \multicolumn{4}{c|}{ Mangrove } & \multicolumn{4}{c}{ Visitation Area } \\
\cline { 2 - 11 } & $\mathrm{N}$ & Min-Max & $\mathrm{Ta}$ & $\mu \pm \mathrm{SD}$ & $\mathrm{N}$ & Min-Max & Ta & $\mu \pm \mathrm{SD}$ \\
\hline Moving & 372 & $34-103$ & 69 & $62.0 \pm 25.0$ & 344 & $47-82$ & 35 & $57.3 \pm 12.8$ \\
\hline Resting & 238 & $5-66$ & 61 & $39.7 \pm 23.5$ & 219 & $11-79$ & 68 & $36.5 \pm 26.3$ \\
\hline Stationary & 191 & $14-48$ & 34 & $31.8 \pm 13.1$ & 212 & $24-60$ & 36 & $35.3 \pm 15.7$ \\
\hline Foraging & 218 & $7-52$ & 45 & $36.3 \pm 16.8$ & 145 & $11-41$ & 30 & $24.2 \pm 11.3$ \\
\hline Playing & 111 & $11-28$ & 17 & $18.5 \pm 6.1$ & 169 & $9-50$ & 41 & $28.2 \pm 17.2$ \\
\hline Feeding & 64 & $2-21$ & 19 & $10.7 \pm 7.9$ & 113 & $2-38$ & 36 & $18.8 \pm 15.1$ \\
\hline Social grooming & 98 & $4-37$ & 33 & $16.3 \pm 11.9$ & 69 & $2-18$ & 16 & $11.5 \pm 5.7$ \\
\hline
\end{tabular}

Table 5. Monthly mean values by area use, difference, studentized range $(\mathrm{Q})$ and $\mathrm{p}$ of the comparison between the means of foraging and feeding by area of use, obtained for the Callithrix jacchus group observed between September 2012 and February 2013, in the Espaço Ciência museum, Olinda, Pernambuco state, Brazil. Legends: C1 = first category of the line; $C 2=$ second category of the line; ns = not significant.

\begin{tabular}{|c|c|c|c|c|}
\hline Categories & Means C1-C2 & Difference & Q & $\mathrm{p}$ \\
\hline Foraging in mangrove (C1) and Foraging in visitation area (C2) & $36.3-24.2$ & 12.1 & 2.2 & ns \\
\hline Foraging in mangrove (C1) and Feeding in mangrove (C2) & $36.3-10.7$ & 25.6 & 4.7 & $<0.05$ \\
\hline Foraging in mangrove $(\mathrm{C} 1)$ and Feeding in visitation area $(\mathrm{C} 2)$ & 36.3-18.8 & 17.5 & 3.2 & ns \\
\hline Foraging in visitation area (C1) and Feeding in mangrove (C2) & $24.2-10.7$ & 13.5 & 2.4 & ns \\
\hline Foraging in visitation area (C1) and Feeding in visitation area (C2) & $24.2-18.8$ & 5.4 & 0.9 & ns \\
\hline Feeding in visitation area (C1) and Feeding in mangrove (C2) & $18.8-10.7$ & 8.1 & 1.5 & ns \\
\hline
\end{tabular}

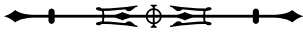


Adult marmosets interacted with night herons Nyctanassa violacea (Linnaeus, 1758) (Aves: Ardeidae), a species associated with wetlands. The birds behaved agonistically, waving their feathers and flapping in the presence of marmosets, especially when the animals attempted to approach their nests. An attempt of physical contact with a crab, Goniopsis cruentata (Latreille, 1803) (Crustacea: Brachyura: Grapsidae), probably to capture it, was also observed.

The presence of domestic dogs Canis familiaris (Linnaeus, 1758) (Mammalia: Canidae) on two different occasions caused the marmosets to emit alert vocalizations, encouraging the group to seek protection in the mangrove foliage. On one occasion a dog approached the marmosets observing other animals in the Chico Science Mangrove, while the marmosets vocalized in a continuous and agonistic way, until one of the marmosets attacked the dog by defensively jumping on its back.

Objects introduced by humans, set up for other studies conducted simultaneously to ours, were used by the group of marmosets to perform certain behavioral activities. Buckets used to collect Aedes aegypti (Linnaeus, 1762) (Diptera: Culicidae) mosquito eggs in the visitation area and nets to collect biological material in the mangrove were used by infants and young $(n=153)$ as well as by adults $(n=$ 10) for playing. Due to the velocity of the play movements, during which they often formed a type of entangled 'animal ball', with several individuals rolling together, it was not always possible to identify the subjects involved $(n=117)$.

A dead marmoset, likely a victim of electrocution, was found a few meters outside the boundaries of the Espaço Ciência museum. Due to the proximity of the corpse to the area frequented by the monitored group, it is possible that this was one of the animals that had dispersed from the study group. Reports by the museum monitors and local workers often mention marmosets and other animal mortalities due to electrocution and roadkill in the vicinity of the museum. On one occasion, the group of marmosets was on a tree on the edge of a viaduct that passes over the museum, however, the animals did not remain there for a long time due to the sound of the passing vehicles.

\section{DISCUSSION}

\section{ACTIVITIES PATTERN IN THE URBAN LANDSCAPE}

Our results show that the overall time devoted to moving, resting, stationary, foraging and playing behaviors was similar to the behavioral pattern exhibited by C. jacchus (Martins, 2007; Amora et al., 2013) and Callitrhix spp. (Modesto \& Bergallo, 2008) in natural environments. However, the distribution of the activities differed between the study group and wild marmosets, as moving or displacement was the least represented behavior by C. jacchus in the Caatinga (Martins, 2007; Amora et al., 2013), but it was frequently observed in congeners and conspecifics that inhabit the Atlantic Forest whereas, animals inhabiting the anthropic area devoted more time to resting and foraging (Modesto \& Bergallo, 2008).

Moving also accounted for highest percentage in two groups of C. jacchus studied by Silva, G. et al. (2011) in urban areas, totalizing respectively $28 \%$ and $48.6 \%$ of the activity patterns, respectively, whereas one of the groups resting was the second most frequent behavior with $24.1 \%$. Displacement was also found to be the highest occurring behavior in urban groups of Callithrix penicillata (É. Geoffroy, 1812) with $22.4 \%$, followed by resting, with a percentage of $16.58 \%$ and inactive alert with $14.95 \%$ (Santos, M. et al., 2014) (equivalent to stationary) and therefore, these results are in accordance with the behavior pattern of $C$. jacchus observed in the museum study area. Although fragmentation and human disturbance affect the activity pattern and spatial and temporal use of wild animal habitat (Tigas et al., 2002; Ditchkoff et al., 2006), the high movement of visitors in the museum grounds and the loud noise from the surrounding highway, did not impede moving behaviors of $C$. jacchus. This is especially important since moving is necessary for food acquisition and consequent intake of enough nutrients for the performance of other individual and social activities.

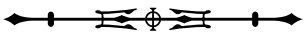




\section{DIET: NATURAL FOODS $X$}

\section{HUMAN-PROVIDED FOODS}

The results showed the inclusion of gum, fruits, flowers, invertebrates, vertebrates and bird eggs in the diet of the study group, reaffirming the omnivorous diet of $C$. jacchus (Digby et al., 2007; Power \& Myers, 2009) and also the inclusion of human-provided foods. Gomivory is an important aspect of the behavioral ecology of $C$. jacchus and their specialized anterior dentition, robust lower incisors lacking lingual enamel, canine height reduction, reduced condylar height, longer jaw-muscle fibers and the enlarged intestinal cecum allows for the inclusion of large amounts of gum in the diet, which is an important food component for marmosets in free-living, natural or urban areas (Rosenberger, 1978; Vinyard et al., 2009; Smith, 2010; Silva, J. et al., 2014; Garbino, 2015).

The amount of gum ingested in natural and urban environments may be different. This difference can be explained by primates' access to food which has been improperly disposed of or through food being offered to these animals on purpose by humans, as a means to attract the animals for closer observation, as was observed in the study site. Additionally, the urban landscapes can make it difficult for animals to access trees that, when present, could serve as a source of food. In an urban environment, outside the native range of the species, gum was found to be the main food source for $C$. jacchus accounting for approximately $40 \%$ of their diet, besides fruits and vertebrates which were ingested in smaller quantities (Cunha et al., 2006). Silva, J. et al. (2014) monitored a group of $C$. jacchus in an urban park surrounded by Atlantic Forest, within the species' native range, and in this case, gum composed $61.9 \%$ of the diet, besides the food provided and other foods of vegetal and animal origin.

The diet of another congener, Callithrix geoffroyi (Humboldt, 1812), studied in urban areas was found to be comprised of $40.7 \%$ gum and $28 \%$ fruits, which represents more than half of the total food intake (Nicolaevsky \& Mendes, 2011). Unlike other studies
(Cunha et al., 2006; Nicolaevsky \& Mendes, 2011; Veríssimo et al., 2012; Silva, J. et al., 2014), we observed that gum was a secondary food item in the diet of the marmosets observed in our study site. However, gum consumption in our study has assumed the same secondary role in the diet of the animals studied by Amora et al. (2013). In the cited study, the proportion of gum in the diet of $C$. jacchus in the Caatinga (28.73\% of the diet) was different from the diet of $C$. jacchus in the museum (11\%), in relation to the other foods consumed in the diet in each study. The predation of bird eggs and nestlings by $C$. jacchus occurs in their natural environment and although birds demonstrate agonistic behaviors, the marmosets often succeed in this activity (Lyra-Neves et al., 2007). As with the group monitored in this study, Begotti \& Landesmann (2008) also described the predation of nests by Callithrix spp. hybrids in urban areas and emphasized that the local avifauna can be harmed by this type of behavior.

Human-provided foods, i.e. exotic fruits and industrialized items, comprised more than half the study group diet and were obtained through interactions with humans, collected in dumpsters or picked off the ground. The same foraging strategy was used by other species of monkeys in urban areas that fed on human foods (Sabbatini et al., 2006; Nicolaevsky \& Mendes, 2011; Albuquerque \& Oliveira, M., 2014; Silva, J. et al., 2014). The availability of human food in urban areas can modify the foraging patterns and diets of wild animals, promoting dramatic differences in dietary habits (Ditchkoff et al., 2006) and the behavior of the $C$. jacchus group in the study area corroborates the effects of the presence of this type of food.

\section{RELATIONSHIP BETWEEN URBAN}

\section{LANDSCAPE, HOME RANGE AND BEHAVIOR OF COMMON MARMOSETS}

The home range of $C$. jacchus can vary between at least one and five hectares in natural and urban environments. 
Groups of marmosets in natural environments were found to have home ranges of 4.9 ha (Alonso \& Langguth, 1989), 0.7 ha and 2.4 ha (Castro, 2003) in the Atlantic Forest, 1.1 ha and 1.5 ha (Veríssimo et al., 2012) in the Restinga and 2.7 ha (De la Fuente et al., 2014) in the Caatinga. In urban environments, groups of marmosets have been found to have home ranges of between 0.2 ha and 4.1 ha (Mendes Pontes \& Monteiro da Cruz, 1995), 0.6 ha (Oliveira, I., 2003), 4.7 ha (Albuquerque et al., 2012), 1.9 ha and 3.4 ha (Rocha, 2019). Therefore, there does not appear to be much difference in the home range size of $C$. jacchus in urban and natural areas. In the same way, 2 ha of mangroves and part of the surrounding visitation area used by the study marmosets, is within the described limits for the home range sizes of marmosets observed in the previous studies. Comparatively, the movement and home range size of common raccoons Procyon lotor (Linnaeus, 1758), living in urban and suburban areas in Northeastern Illinois, has been found to be lower in relation to the animals living in rural areas due to the abundant presence of artificial foods (Prange et al., 2004).

In accordance with all these studies, the influence of the urban environment on the marmosets group observed at the Espaço Ciência museum was evidenced by the frequency of certain activities, which were carried out more often in the mangrove, where marmosets took advantage of the shading provided by vegetation. We noted that the group made fewer trips to open areas, which experienced higher temperatures and greater noise levels from people and vehicle traffic, and sought food mainly in the visitation area, where success was almost always guaranteed. This strategy optimized the acquisition of nutrients to meet the energy needs of the animals. Thus, the study marmosets group also demonstrated a similar adaptation to that of raccoons, observed in a study by Prange et al. (2004), reducing their home range, diversifying their diet and avoiding risks. There was no significant difference in the use of the mangrove and visitation areas by the group of marmosets. Although the occurrence of moving, resting, foraging and social grooming activities was higher in the Chico Science Mangrove, and the stationary, playing and feeding activities were more common in the visitation area, there was no significant difference in the performance of these activities between any of the locations. In contrast, the $C$. jacchus group studied by Albuquerque et al. (2012) in the Atlantic Forest of Pernambuco state, demonstrated a preference for the visitation area in an urban park for the performance of displacement, social grooming and playing activities, instead of remaining in the forest area.

Regarding the activities associated with diet, foraging was significantly more common compared to feeding in the mangrove $(p<0.05)$. The mangrove is a place with a myriad of microhabitats for small vertebrates and insects, items that usually required a significant amount of time to find and whose capture is not always successful as these prey are large, mobile and may use camouflage to avoid predators (Digby et al., 2007). Foods readily available, such as gums, fruits and, especially, human-provided food, were found and consumed, on most occasions, in the visitation area and occasionally human-provided food was placed on the branches of the mangrove by humans for the marmosets. Direct and indirect contact between the public and the $C$. jacchus group involving food was observed. The study area was a place of public visitation, with people passing by and often stopping in close proximity to gaze at the animals or to observe their behavior, they used food to attract the marmosets. Similarly, Paula et al. (2005), Leite et al. (2011), and Albuquerque \& Oliveira, M. (2014) mentioned the use of food by people to attract Callithrix spp., C. penicillata and C. jacchus, respectively.

The study marmosets interacted agonistically with the mangrove night heron $\mathrm{N}$. violacea. Lyra-Neves et al. (2007) also described behaviors such as flying over and blows with the beak or breast by birds as antipredatory behavior, as an attempt to make marmosets move away from the nests. Furthermore, on two occasions adult marmosets observed the crab, G. cruentata, with an unsuccessful contact attempt. Cutrim (2013), in its turn, 
observed the inclusion of crustaceans, gastropods and bivalves in the diet of Sapajus libidinosus (Spix, 1823) in a mangrove fragment and Santos, A. S. (2011) reported the predation of the crab, Aratus pisonii $(\mathrm{H}$. Milne Edwards, 1837) by Callithrix kuhlii (Wied, 1826) in Bahia state, northeastern Brazil. However, the crab G. cruentata was not eaten by the study group.

The presence of domestic dogs during two different occasions elicited the emission of alert vocalizations by the marmosets, after which the group sought protection in the mangrove and on one of the occasions, the marmosets attacked the dog. Free-living domestic dogs can chase and kill primates, as described by Srbek-Araujo \& Chiarello (2008), who even reported the predation of a mediumsized primate, the titi monkey Callicebus personatus (É. Geoffroy, 1812). To mitigate the effects of predation on capuchin monkeys Sapajus nigritus (Goldfuss, 1809), Oliveira, V. et al. (2008) proposed an action plan which involved the capture and removal of the dogs.

During playing activities, the common marmosets used objects introduced by humans. This behavior allows for the exploration of the environment and neuromotor and cognitive development in young individuals and infants (Santos, A. C. et al. , 2010). As objects were usually hidden in the vegetation, the selection of play sites might be associated with sites safe from predator attacks (Cavalheiro, 2008). One marmoset was found dead, thought to be a victim of electrocution, a consequence of the negative effects of urban land use on local biodiversity (McKinney, 2008). In the urban environment, marmosets can use electric wires as bridges and, when they do not die, they commonly suffer burns or limb amputation (Oliveira, M., 2008).

\section{CONCLUSION}

The behavior of the study marmosets, $C$. jacchus, and the exploration of their home range were adjusted according to the environment in which they were inserted and what it had to offer, allowing for their survival. On the other hand, certain aspects of the urban landscape and anthropic activities in this environment interfered, in different ways, on the relationships between $C$. jacchus and the biotic and abiotic factors of the urban ecosystem.

In our study, the behavior of the marmosets inhabiting the urban mangrove within an outdoor museum was similar to other studies with primates and other wild animals in urban areas, exposed to high circulations of people and different from primate studies in natural areas, particularly in relation to diet. The results of this study will contribute to the continuous monitoring of nonhuman primates living in urban areas and thus outline future actions that may support strategies mitigating the putative and actual conflicts caused by a disturbed environment and by animals and humans living in urban areas.

\section{ACKNOWLEDGMENT}

We thank the management of the Espaço Ciência museum, represented by Dr. Antonio Carlos Pavão, for authorizing the study. Pedro Aguilar Cescon and Rebecca Nimrah Umeed for revising the text. We are grateful to Guilherme Garbino e two anonym reviewers for their valuable suggestions and comments in a previous version of the manuscript.

\section{REFERENCES}

ADAMS, L. W., 2005. Urban wildlife ecology and conservation: a brief history of the discipline. Urban Ecosystems 8(2): 139-156. DOI: https://doi.org/10.1007/s11252-005-4377-7

ALBUQUERQUE, J. R., J. M. SILVA, M. A. B. OLIVEIRA \& V. L. SILVA, 2012. Tamanho e uso da área domiciliar por um grupo silvestre de Callithrix jacchus (Primates: Cebidae: Callitrichinae) no Parque Estadual Dois Irmãos, Recife-PE. Revista Nordestina de Zoologia 6(2): 1-18

ALBUQUERQUE, J. R. \& M. A. B. OLIVEIRA, 2014. Interações entre humanos e Callithrix jacchus (Linnaeus, 1758) no Parque Estadual Dois Irmãos, Recife-PE, Brasil. In: F. C. PASSOS \& J. M. D. MIRANDA (Ed.): A primatologia no Brasil: vol. 13: 110-123. SBPr, Curitiba.

ALONSO, C. \& A. LANGGUTH, 1989. Ecologia e comportamento de Callithrix jacchus (Primates: Callitrichidae) numa ilha de Floresta Atlântica. Revista Nordestina de Biologia 6(2): 105-137.

ALTMANN, J., 1974. Observational study of behaviour: sampling methods. Behaviour 49(3): 227-267. DOI: http://doi. org/10.1163/156853974X00534 
AMORA, T. D., R. BELTRÃO-MENDES \& S. F. FERRARI, 2013. Use of alternative plant resources by common marmosets (Callithrix jacchus) in the semi-arid caatinga scrub forests of northeastern Brazil. American Journal of Primatology 75(4): 333-341. DOI: http://doi. org/10.1002/ajp.22110

ANGELICI, F. M., 2016. Problematic wildlife at the beginning of the Twenty-First Century: Introduction. In: F. M. ANGELICI (Ed.): Problematic wildlife: a cross-disciplinary approach: 3-18. Springer, New York. DOI: http://doi.org/10.1007/978-3-319-22246-2_1

BEGOTTI, R. A. \& L. F. LANDESMANN, 2008. Predação de ninhos por um grupo híbrido de sagüis (Callithrix jacchus/penicillata) introduzidos em área urbana: implicações para a estrutura da comunidade. Neotropical Primates 15(1): 28-29. DOI: http://doi. org/10.1896/044.015.0107

BRADLEY, C. A. \& S. ALTIZER, 2007. Urbanization and the ecology of wildlife diseases. Trends in Ecology and Evolution 22(2): 95-102. DOI: http://doi.org/10.1016/j.tree.2006.11.001

CASTRO, C. S. S., 2003. Tamanho da área de vida e padrão de uso do espaço em grupos de sagüis Callithrix jacchus (Linnaeus) (Primates, Callitrichidae). Revista Brasileira de Zoologia 20(1): 91-96. DOI: https://doi.org/10.1590/S0101-81752003000100011

CAVALHEIRO, M. C., 2008. O brincar em saguis (Callithrix penicillata) (Primates: Callitrichidae) sob o foco da teoria do excedente de energia. Masther Dissertation - Universidade de Brasília, Brasília.

CUNHA, A. A., M. V. VIEIRA \& C. E. GRELLE, 2006. Preliminary observations on habitat, support use and diet in two non-native primates in an urban Atlantic forest fragment: the capuchin monkey (Cebus sp.) and the common marmoset (Callithrix jacchus) in the Tijuca forest, Rio de Janeiro. Urban Ecosystems 9: 351-359. DOI: https://doi.org/10.1007/s11252-006-0005-4

CUTRIM, F. H. R., 2013. Padrão comportamental e uso de ferramentas em macacos-prego (Sapajus libidinosus) residentes em manguezal. Doctoral Thesis - Universidade de São Paulo, São Paulo.

DE LA FUENTE, M. F. C., A. SOUTO, M. B. SAMPAIO \& N. SCHIEL, 2014. Behavioral adjustments by a small neotropical primate (Callithrix jacchus) in a semiarid caatinga environment. The Scientific World Journal 2014: 326524. DOI: https://doi. org/10.1155/2014/326524

DIGBY, L. J., S. F. FERRARI \& W. SALTZMAN, 2007. Callitrichines: the role of competition in cooperatively breeding species. In: C. J. CAMPBELL, A. FUENTES, K. C. MACKINNON, M. A. PANGER \& S. K. BEARDER (Ed.). Primates in perspective: 85-106. Oxford University Press, New York.

DITCHKOFF, S. S., S. T. SAALFELD \& C. J. GIBSON, 2006. Animal behavior in urban ecosystems: modifications due to human-induced stress. Urban Ecosystems 9(1): 5-12. DOI: https://doi.org/10.1007/ s11252-006-3262-3
GARBINO, G. S. T., 2015. How many marmoset (Primates: Cebidae: Callitrichinae) genera are there? A phylogenetic analysis based on multiple morphological systems. Cladistics 31(6): 652-678. DOI: https://doi.org/10.1111/cla.12106

GOULART, V. D. L. R., C. P. TEIXEIRA \& R. J. YOUNG, 2010. Analysis of callouts made in relation to wild urban marmosets (Callithrix penicillata) and their implications for urban species management. European Journal Wildlife Research 56: 641-649. DOI: https://doi.org/10.1007/s10344-009-0362-4

HADIDIAN, J., 1992. Interactions between people and wildlife in urbanizing landscapes. Conservation Biology 15: 216-227.

HADIDIAN, J. \& S. SMITH, 2001. Urban wildlife. In: D. J. SALEM \& A. N. ROWAN (Ed.): The state of the animals: 165-182: The Humane Society Press, Washington, DC.

INSTITUTO BRASILEIRO DE GEOGRAFIA E ESTATÍSTICA(IBGE), 2020. Mapas escolares. Available at: https://mapas.ibge.gov.br/ escolares. Accessed on: November 1, 2020.

JOKIMÄKI, J., M. KAISANLAHTI-JOKIMÄKI, J. SUHONEN, P. CLERGEAU, M. PAUTASSO \& E. FERNÁNDEZ-JURICIC, 2011. Merging wildlife community ecology with animal behavioral ecology for a better urban landscape planning. Landscape and Urban Planning 110(4): 383-385. DOI: https://doi.org/10.1016/j. landurbplan.2011.02.001

KHAIRNAR, S. O., A. R. SATHE, V. D. MHATRE, S. S. JADHAV \& K. B. DESAI, 2009. Mangrove biodiversity of India. Aqua International 16(12): 29-30.

LEITE, G. C., M. H. L. DUARTE \& R. J. YOUNG, 2011. Humanmarmoset interactions in a city park. Applied Animal Behaviour Science 132(3-4): 187-192. DOI: https://doi.org/10.1016/j. applanim.2011.03.013

LOWRY, H., A. LILL \& B. B. M. WONG, 2013. Behavioural responses of wildlife to urban environments. Biological Reviews 88(3): 537-549. DOI: https://doi.org/10.1111/brv.12012

LUNIAK, M., 2004. Synurbization-adaptation of animal wildlife to urban development. In: W. W. SHAW, L. K. HARRIS \& L. VANDRUFF (Ed.): Proceedings of the 4th International Symposium on Urban Wildlife Conservation: 50-55. University of Arizona, Arizona.

LYRA-NEVES, R. M., M. A. B. OLIVEIRA, W. R. TELINO-JÚNIOR \& E. M. SANTOS, 2007. Comportamentos interespecíficos entre Callithrix jacchus (Linnaeus) (Primates: Callitrichidae) e algumas aves de Mata Atlântica, Pernambuco, Brasil. Revista Brasileira de Zoologia 24(3): 709-716. DOI: https://doi.org/10.1590/S010181752007000300022

MAGLE, S. B., V. M. HUNT, M. VERNON \& K. R. CROOKS, 2012. Urban wildlife research: past, present, and future. Biological Conservation 155: 23-32. DOI: https://doi.org/10.1016/j. biocon.2012.06.018

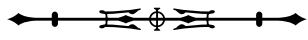


MARION, W. R., 1988. Urban wildlife: can we live with them? In: A. C. CRABB \& R. E. MARSH (Ed.): Proceedings of the Thirteenth vertebrate pest conference: 13: 34-38. Universidade da Califórnia em Davis, Davis.

MARTINS, I. G., 2007. Padrão de atividades do sagui Callithrix jacchus numa área de Caatinga. Masther Dissertation - Universidade Federal do Rio Grande do Norte, Natal.

MCKINNEY, M. L., 2008. Effects of urbanization on species richness: A review of plants and animals. Urban Ecosystems 11(2): 161-176. DOI: https://doi.org/10.1007/s11252-007-0045-4

MENDES PONTES, A. R. \& M. A. O. MONTEIRO DA CRUZ, 1995. Home range, intergroup transfers, and reproductive status of common marmosets Callithrix jacchus in a forest fragment in North-Eastern Brazil. Primates 36(3): 335-347. DOI: https://doi. org/10.1007/BF02382857

MENDES PONTES, A. R. \& M. L. SOARES, 2005. Sleeping sites of common marmosets (Callithrix jacchus) in defaunated urban forest fragments: a strategy to maximize food intake. Journal of Zoology 266(1): 55-63. DOI: https://doi.org/10.1017/S095283690500662X

MODESTO, T. C. \& H. G. BERGALLO, 2008. Ambientes diferentes, diferentes gastos do tempo entre atividades: o caso de dois grupos mistos do exótico Callithrix spp. na Ilha Grande, RJ, Brasil. Neotropical Biology and Conservation 3(3): 112-118. DOI: https:// doi.org/10.4013/nbc.20083.02

MONTEIRO DA CRUZ, M. A. O., 1998. Dinâmica reprodutiva de uma população de saguis-do-nordeste (Callithrix jacchus) na Estação Ecológica do Tapacurá, PE. Doctoral Thesis - Universidade de São Paulo, São Paulo.

MUCELIN, C. A. \& M. BELLINI, 2008. Lixo e impactos ambientais perceptíveis no ecossistema urbano. Sociedade \& Natureza 20(1): 111-124. DOI: https://doi.org/10.1590/S1982-45132008000100008

NICOLAEVSKY, B. \& S. L. MENDES, 2011. Comportamento alimentar do sagüi-da-cara-branca, Callithrix geoffroyi (É. Geoffroy in Humboldt, 1812) (Primates, Callitrichidae), em ambiente urbano. In: J. M. D. MIRANDA \& Z. M. B. HIRANO (Ed.): A primatologia no Brasil: vol. 11: 52-61. SBPr, Curitiba.

OLIVEIRA, I. A. A., 2003. Padrão de dispersão e análise da área de uso de uma população urbana de sagüis-do-nordeste Callithrix jacchus (Callitrichidae, Primates). Masther Dissertation - Universidade Federal de Pernambuco, Recife.

OLIVEIRA, M. A. B., 2008. Ética e bem-estar em animais silvestres: Primatas. Ciência Veterinária dos Trópicos (1): 56-58

OliveirA, V. B., A. M. LiNARES, G. L. C. CORRÊA \& A. G. CHIARELLO, 2008. Predation on the black capuchin monkey Cebus nigritus (Primates: Cebidae) by domestic dogs Canis lupus familiaris (Carnivora: Canidae), in the Parque Estadual Serra do Brigadeiro, Minas Gerais, Brazil. Revista Brasileira de Zoologia 25(2): 376-378. DOI: https://doi.org/10.1590/\$0101-81752008000200026
PARKER, T. S. \& C. H. NILON, 2012. Urban landscape characteristics correlated with the synurbization of wildlife. Landscape and Urban Planning 106(4): 316-325. DOI: https:// doi.org/10.1016/j.landurbplan.2012.04.003

PAULA, H. M. G., R. S. TÁVORA, M. V. ALMEIDA, L. S. PELEGRINI, G. V. SILVA, R. L. ZAGANINI \& A. LUCINDO, 2005. Estudos preliminares da presença de sagüis no município de Bauru, São Paulo, Brasil. Neotropical Primates 13(3): 6-11. DOI: http://dx.doi.org/10.1896/1413-4705.13.3.6

PERIQUITO, M. C., G. A. PEREIRA \& M. T. BRITO, 2008. Aves no manguezal do Espaço Ciência, Olinda, Pernambuco. Atualidades Ornitológicas On-line (145): 36-38.

POESSEL, S. A., E. M. GESE \&J. K. YOUNG, 2017. Environmental factors influencing the occurrence of coyotes and conflicts in urban areas. Landscape and Urban Planning 157: 259-269. DOI: https://doi.org/10.1016/j.landurbplan.2016.05.022

POWER, M. L. \& W. MYERS, 2009. Digestion in the common marmoset (Callithrix jacchus), a gummivore-frugivore. American Journal of Primatology 71(12): 957-963. DOI: https://doi. org/10.1002/ajp.20737

PRANGE, S., S. D. GEHRT \& E. P. WIGGERS, 2004. Influences of anthropogenic resources on raccon (Procyon lotor) movements and spatial distribution. Journal of Mammalogy 85(3): 483-490. DOI: https://doi.org/10.1644/BOS-121

PREFEITURA DA CIDADE DO RECIFE (PCR), 2020. Caracterização de território, Prefeitura do Recife. Available at: http://www2.recife.pe.gov.br/pagina/caracterizacao-do-territorio. Accessed on: November 1, 2020.

RANGEL, C. H., F. S. F. SOUSA \& C. E. GRELLE, 2011. Dieta de Callithrix jacchus (Linnaeus, 1758) e Callithrix penicillata (E. Geoffroy, 1812) (Callitrichidae - Primates) e seus híbridos, alóctones no Jardim Botânico do Rio de Janeiro. In: J. M. D. MIRANDA \& Z. M. B. HIRANO (Ed.): A primatologia no Brasil: vol. 11: 74-84. SBPr, Curitiba.

ROCHA, P. I. A., 2019. Efeito da dieta nas atividades de dois grupos de vida livre de saguis do Nordeste (Callithrix jacchus) do Parque Estadual do Dois Irmãos, Recife, Pernambuco, Brasil. Monography - Universidade Federal Rural de Pernambuco, Recife.

ROSENBERGER, A. L., 1978. Loss of incisor enamel in marmosets. Journal of Mammalogy 59(1): 207-208. DOI: https://doi. org/10.2307/1379899

RUIZ-MIRANDA, C. R., A. G. AFFONSO, A. MARTINS \& B. BECK, 2000. Distribuição do sagui (Callithrix jacchus) nas áreas de ocorrência do mico-leão-dourado (Leontopithecus rosalia) no estado do Rio de Janeiro. Neotropical Primates 8(3): 98-101.

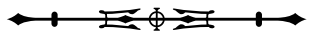


RYLANDS, A. B., A. F. COIMBRA-FILHO \& R. A. MITTERMEIER, 2009. The systematics and distributions of the Marmosets (Callithrix, Callibella, Cebuella, and Mico) and Callimico (Callimico) (Callitrichidae, Primates). In: S. M. FORD, L. M. PORTER \& L. C. DAVIS (Ed.): The smallest anthropoids: the Marmoset/Callimico radiation: 25-61. Springer, New York.

RYLANDS, A. B. \& R. A. MITTERMEIER, 2013. Family Callitrichidae (marmosets and tamarins). In: R. A. MITTERMEIER, A. B. RYLANDS \& D. E. WILSON (Ed.): Handbook of the Mammals of the World: vol. 3: Primates: 262-346. Lynx Edicions, Barcelona.

SABBATINI, G., M. STAMMATI, M. C. H. TAVARES, M. V. GIULIANI \& E. VISALBERGHI, 2006. Interactions between humans and capuchin monkeys (Cebus libidinosus) in the Parque Nacional de Brasília, Brazil. Applied Animal Behaviour Science 97(2-4): 272-283. DOI: https://doi.org/10.1016/j. applanim.2005.07.002

SANTOS, A. C. L., M. P. MNEGUSSO, V. BOTTNCOURT, R. MOURA \& P. G. B. S. DIAS, 2010. Comportamento de brincadeiras em um grupo de saguis-de-tufo-preto Callithrix penicillata (Geoffroy, 1812) cativos do zoológico Bosque Guarani, Foz do Iguaçu, PR. Pleiade 7(7): 7-32.

SANTOS, A. S. R., 2011. Predation of marine crab (Aratus pisonii) by Weid's black tufted-ear marmoset (Callithrix kuhlii) in mangroves of Comandatuba Island, Una, Bahia, Brazil. Available at: http://www.aultimaarcadenoe.com.br/wp-content/uploads/2011/06/ Predation-of-marine-creb-by-Callithrix-kuhlii_IComadatuba-BA_ASingles.pdf. Accessed on: November 2, 2020.

SANTOS, M. N., M. H. L. DUARTE \& R. J. YOUNG, 2014. Behavioural and ecological aspects of black tufted-ear marmosets, Callithrix penicillata (Geoffroy, 1812) (Primates: Callitrichidae) in a semi-urban environment. Revista de Etologia 13(1): 37-46.

SECRETARIA DE CIÊNCIA, TECNOLOGIA E INOVAÇÃO DO ESTADO DE PERNAMBUCO (SECTEC), 2016. Espaço Ciência. Available at: http://www.sectec.pe.gov.br/web/sectec/espacociencia. Accessed on: February 7, 2016.

SILVA, G. S. \& M. A. O. MONTEIRO DA CRUZ, 1993. Comportamento e composição de um grupo de Callithrix jacchus Erxleben (Primates, Callitrichidae) na mata de Dois Irmãos, Recife, Pernambuco, Brasil. Revista Brasileira de Zoologia 10(3): 509-520. DOI: https://doi.org/10.1590/S0101-81751993000300018

SILVA, G. M. M., K. C. S. VERÍSSIMO \& M. A. B. OLIVEIRA, 2011. Orçamento das atividades diárias de dois grupos de Callithrix jacchus em área urbana. Revista de Etologia 10(2): 57-63.

SILVA, J. M., J. R. ALBUQUERQUE \& M. A. B. OLIVEIRA, 2014. Em busca de alimento: um estudo sobre a influência de itens providos por humanos na dieta de um grupo de Callithrix jacchus (Linnaeus 1758) de vida livre, no Parque Estadual Dois Irmãos, Recife-PE, Brasil. In: F. C. PASSOS \& J. M. D. MIRANDA (Ed.): A primatologia no Brasil: vol. 13: 152-160. SBPr, Curitiba.
SILVA, M. A. F., C. E. VERONA, M. CONDE \& A. S. PIRES, 2018. Frugivory and potential seed dispersal by the exotic-invasive marmoset Callithrix jacchus (Primates, Callitrichidae) in an urban Atlantic Forest, Rio de Janeiro, Brazil. Mammalia 82(4): 343-349. DOI: https://doi. org/10.1515/mammalia-2016-0075

SMITH, A. C., 2010. Exudativory in primates: interspecific patterns. In: A. M. BURROWS \& L. T. NASH (Ed.): The evolution of exudativory in primates: 45-88. Springer, New York.

SOULSBURY, C. D. \& P. C. L. WHITE, 2015. Human-wildlife interactions in urban ecosystems. Wildlife Research 42(7): 3-5. DOI: https://doi.org/10.1071MRv42n7_PR

SOUZA, R. M., 2006. Alterações na paisagem urbana: uma análise morfodinâmica da área do entorno do Manguezal Chico Science, Olinda-PE. Masther Dissertation - Universidade Federal de Pernambuco, Recife.

SRBEK-ARAUJO, A. C. \& A. G. CHIARELLO, 2008. Domestic dogs in Atlantic forest preserves of south-eastern Brazil: a camera-trapping study on patterns of entrance and site occupancy rates. Brazilian Journal of Biology 68(4): 771-779. DOI: https://doi.org/10.1590/ S1519-69842008000400011

TIGAS, L. A., D. H. V. VUREN \& R. M. SAUVAJOT, 2002. Behavioral responses of bobcats and coyotes to habitat fragmentation and corridors in an urban environment. Biological Conservation 108(3): 299-306. DOI: https://doi.org/10.1016/S0006-3207(02)00120-9

TRAAD, R. M., J. C. M. LEITE, P.WECKERLIN \& S. TRINDADE, 2012. Introdução das espécies exóticas Callithrix penicillata (Geoffroy, 1812) e Callithrix jacchus (Linnaeus, 1758) em ambientes urbanos (Primates: Callithrichidae). Revista Meio Ambiente e Sustentabilidade 2(1): 9-23.

VANNUCCI, M., 2001. What is so special about mangroves? Brazilian Journal of Biology 61(4): 599-603. DOI: https://doi.org/10.1590/ S1519-69842001000400008

VERÍSSIMO, K. C. S., L. IANNUZZI \& M. A. B. OLIVEIRA, 2012. Callithrix jacchus (Linnaeus, 1758) em uma restinga de Pernambuco: influência da distribuição espacial da vegetação sobre a área de uso. In: A. C. A. EL-DEIR, G. J. B. MOURA \& O. E. L. ARAÚJO (Ed.): Ecologia e conservação de ecossistemas no Nordeste do Brasil: 387-400. Nuppea, Recife.

VINYARD, C. J., C. E. WALL, S. H. WILLIAMS, A. L. MORK, B. A. ARMFIELD, L. C. O. MELO, M. M. VALENÇA-MONTENEGRO, Y. B. M. VALLE, M. A. B. OLIVEIRA, P. W. LUCAS, D. SCHMITT, A. B. TAYLOR \& W. L. HYLANDER, 2009. The evolutionary morphology of tree gouging in marmosets. In: S. M. FORD, L. M. PORTER \& L. C. DAVIS (Ed.): The smallest anthropoids: the marmoset/callimico radiation: 395-409. Springer, New York.

YAMAMOTO, M. E., 1993. From dependence to sexual maturity: the behavioural ontogeny of Callitrichidae. In: A. B. RYLANDS (Ed.): Marmosets and Tamarins: systematics, behaviour, and ecology: 235-250. Oxford University Press, New York.

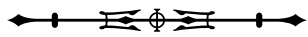

